\title{
Poor glycemic control and associated factors among diabetic patients in Ethiopia; A
} Systemic review and meta-analysis

Berhane Fseha Teklehaimanot ${ }^{1 *}$, Abadi kidanemariam Berhe ${ }^{2}$, Gebrehiwot Gebremariam Welearegawi ${ }^{3}$

${ }^{1}$ Lecturer in Epidemiology \& Biostatistics,Department of public health, College of Medicine and Health Sciences, Adigrat University, Tigray, Ethiopia; E-mail: berhanefish@gmail.com

${ }^{2}$ Assistant professor in Department of Nursing, College of Medicine and Health Sciences, Adigrat University, Tigray, Ethiopia; E-mail: abadik021@gmail.com

${ }^{3}$ Lecturer in reproductive health, Department of Public Health, College of Medicine and Health Sciences, Adigrat University, Tigray, Ethiopia; E-mail: gebrihet@gmail.com

*Correspondence author 


\section{Abstract \\ Introduction}

The major global public health problems now days are diabetes especially the burden is high in low income countries including Ethiopia due to the limited resource for screening and early diagnosis of the diabetes. To prevent diabetic complications including organ damage and micro vascular complications blood glucose level should be maintained at an optimum level. However there was no pooled national picture on poor glycemic control and its associated factors.

\section{Methods}

Different data base searching engine including PubMed, Google scholar, the Cochrane library, MEDLINE, HINARY and African journal online (AJOL) were used. The Joanna Briggs Critical Appraisal Tools and Newcastle Ottawa scale for assessing the quality of cross sectional studies were used for quality assessment. The meta-analysis was conducted using STATA 14 software. $I^{2} \quad$ statistic and egger weighted regression were used to assess heterogeneity and publication bias.

\section{Results}

A total of 134 studies were identified from different database searching engines and other sources. After removing for duplication, absence of abstract and review of the full text 12 studies were including in the meta-analysis. The pooled prevalence of poor glycemic control among diabetic patients in Ethiopia is $64.72 \%$ with $95 \%$ confidence interval $63.16-66.28 \%$. The sub group analysis of poor glycemic control among diabetic patients in different region of the country shows consistent and high prevalence of poor glycemic control ranging from $62.5 \%$ in Tigray region to $65.6 \%$ in Oromia region of the country. Residence, dyslipidemia and diet adherence were significantly association with poor glycemic control among diabetic patients in Ethiopia.

\section{Conclusion}

The prevalence of poor glycemic control among diabetic patients was high in Ethiopia and consistent across different regions of the country. The most important factors associated with poor glycemic factor among diabetic patients were being rural residence, having dyslipidemia and not adhering to dietary plan.

Keywords: Poor glycemic control, diabetes, Fasting blood glucose, glycated hemoglobin, Ethiopia. 


\section{Introduction}

Diabetes is chronic disease occurred due to increased blood glucose level because of the body cannot produce at all or secrets in sufficient insulin hormone or not use it effectively. Hence, the nonexistence of insulin or the cell is not sensitive to use insulin leads to increased blood glucose level which is the hallmark of diabetes(1). Globally 425 million adult population have diabetes and an estimated of 15.5 Millions of them are living in Africa and it is projected that by 2040 about 34.2 million are expected to be diabetic(2). One of the major global public health problems now days are diabetes especially the burden is high in low income countries including Ethiopia due to the limited resource for screening and early diagnosis of the diabetes (3).

To prevent diabetic complications including organ damage and micro vascular complications the blood glucose level should be maintained at an optimum level because poor glycemic control leads to diabetic keto acidosis, cognitive impairment, immune dysfunction and hospital admissions due to May complications. The magnitude of poor glycemic control is high throughout the world and specifically in Ethiopia greater than $50 \%$ of the diabetic patients does not had optimum blood glucose level(4-7).

Several primary Studies have been conducted in Ethiopia on the magnitude of poor glycemic control and their associated factors among diabetic patients. However the result of these studies were not consistent on the prevalence of poor glycemic control and even the factors that have significant association with poor glycemic control among diabetic patients varies across the studies. Moreover, there is no a study that shows the national pooled prevalence of poor glycemic control and contributing factors as well. . Therefore, this systemic review and metaanalysis on poor glycemic control and associated factors in Ethiopia are filling these gap and will generating new attention on the significant contributing factors to maintain the optimum blood glucose level among diabetic patients in Ethiopia. 


\section{Methods}

\section{Study design and search strategy}

A systematic review and meta-analysis on the poor glycemic control and associated factors among diabetic patients in Ethiopia has been conducted. Different data base searching engine including PubMed, Google scholar, the Cochrane library, MEDLINE, HINARY and African journal online (AJOL) were used. Besides, grey literature and the reference list of former studies were also searched for extra articles. The Boolean operators was used to search the articles by using the following key and medical subject hedging terms separately and in combination "glycemic control" "glycemic control", "blood glucose control", "fasting blood glucose", "glycated hemoglobin", prevalence, magnitude, "associated factor", predictors, Ethiopia. Language was limited to be only English. From May 2019 up to July 2019 was the period used to search the studies.

\section{Study selection and eligibility criteria}

\section{Study selection}

Selection of articles for the systemic review and meta-analysis were if the study conducted in Ethiopia and studies reporting poor glycemic control and/or the associated factors. Two independent researchers assessed the abstract and full text of all articles after preliminary screening of the studies for their title. A third researcher has been resolved the disagreement between the two researchers. A total of 134 studies were found from database searching and grey literatures (figure 1). 


\section{Eligibility criteria}

\section{Inclusion}

$\checkmark \quad$ All articles published until the end of July 2019

$\checkmark$ Only researches measured the poor glycemic level and/or associated factors among diabetic patients published and grey literatures were included

$\checkmark$ Fasting blood glucose, oral glucose tolerance test and hemoglobin a one c(Ha1c) measurement for poor glycemic control according to the standard cut off point were included

$\checkmark$ For duplicated articles the most recent were used

$\checkmark$ Only English language published articles were used

\section{Exclusion}

$\checkmark$ Studies used random blood glucose level to determine poor glycemic control were excluded

$\checkmark$ Poor glycemic level that do not adhere to the standard world health organization definition and international diabetic federation were excluded.

$\checkmark$ Article that are rated as low quality assessment was rejected.

$\checkmark$ Studies that have response rate of $<80 \%$ were excluded

\section{Data extraction}

Data extraction form has been developed by two researcher in excel spread sheet format and appraised by the third author. The data abstraction includes author, year of study, year of publication, study area(region of the country), study design, study setting( hospital/community based), sampling technique, sample size, response rate, outcome measured by( fasting blood glucose/ HbA1c), prevalence of poor glycemic control, age, gender, residence(urban/rural), monthly income, educational status, occupation, regular follow up, serum lipid level, presence of comorbidity, duration of disease, physical exercise, medication adherence, diet adherence, type of diabetes(type 1/type 2), medication(insulin, oral and combined), and body mass index (BMI) of the study participant were extracted. In addition to the total prevalence of poor glycemic control and sub categories by region of the country and outcome measured by fasting blood glucose or hemoglobin HbA1c has been extracted. 
medRxiv preprint doi: https://doi.org/10.1101/19004986; this version posted August 22, 2019. The copyright holder for this preprint (which was not certified by peer review) is the author/funder, who has granted medRxiv a license to display the preprint in perpetuity.

It is made available under a CC-BY-NC-ND 4.0 International license .

\section{Operational definition of outcome measures}

Poor glycemic control is the level of blood glucose rages out of the normal value that is Fasting blood glucose measurement greater than $130 \mathrm{mg} / \mathrm{dl}$ and less than $70 \mathrm{mg} / \mathrm{dl}$ and glycated hemoglobin(Ha1c $\geq 7 \%)$.

\section{Study quality and critical appraisal}

Quality of the studies was assessed by the Joanna Briggs Critical Appraisal Tools and Newcastle Ottawa scale for assessing the quality of cross sectional studies in meta-analysis(8). Parameter for quality assessment contains sampling procedure, representativeness in terms of their sample size, response rate, and blood glucose measured by standard measurement tool.

\section{Heterogeneity and publication bias}

Cochranes Q test which shows the presence of heterogeneity among studies and $\mathrm{I}^{2}$ statistic were used to test heterogeneity. The estimate of variation in effect estimate that is due to heterogeneity rather than sampling error or chance differences was evaluated by $\mathrm{I}^{2}$ statistic. Hence, the presence of heterogeneity was checked by Cochranes $Q$ test $(\mathrm{p}<0.10$ indicates statistically significant heterogeneity as cut off point) and the value of $\mathrm{I}^{2}$ test $25 \%, 50 \%, 75 \%$ indicates low, medium and high heterogeneity among studies.

To assess for publication bias egger weighted regression and Begg rank correlation test $(\mathrm{p}<0.05$ were considered as statistical significant publication bias) method used.

\section{Statistical analysis}

The data entry was conducted on Microsoft excel spread sheet for windows 2010 and exported to STATA version 14 statistical software for analysis. Descriptive summary of the original studies were conducted and presented in forest plot, tables and texts. Fixed effect model was used to compute the pooled prevalence with $95 \%$ confidence interval of poor glycemic control since there was no heterogeneity among the articles and random an fixed effect model was computed to identify the factors that had significant association with poor glycemic control among diabetic patients in Ethiopia. 
medRxiv preprint doi: https://doi.org/10.1101/19004986; this version posted August 22, 2019. The copyright holder for this preprint (which was not certified by peer review) is the author/funder, who has granted medRxiv a license to display the preprint in perpetuity.

It is made available under a CC-BY-NC-ND 4.0 International license .

\section{Subgroup analysis}

Subgroup analysis were conducted by region of the country, outcome measured by fasting blood glucose/ or hemoglobin alc and pooled prevalence of the factors was displayed by forest plot with the effct size and 955 confidence intervals.

\section{Result}

\section{Identified studies}

A total of 134 studies were identified from different database searching engines PubMed, Google scholar, the Cochrane library, MEDLINE, HINARY, and African journal online (AJOL). After removing for duplication, absence of abstract and review of the full text does not have the poor glycemic control measurement only 13 studies were eligible to include for meta-analysis. We exclude one article based on the quality assessment result. Finally 12 articles have been included in the meta-analysis. Figure 1 

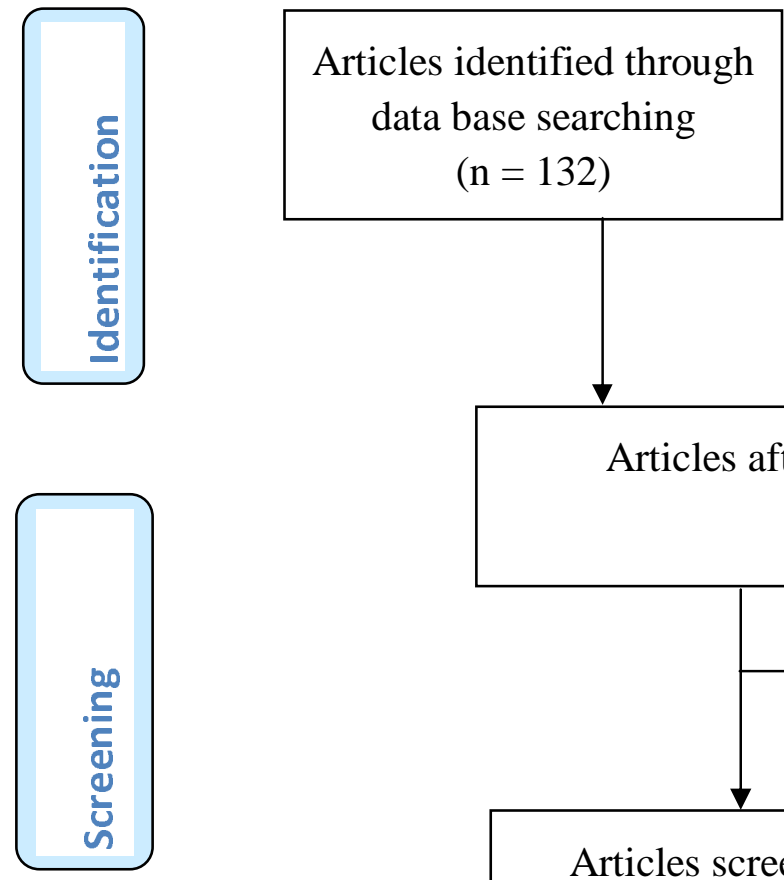
Articles identified through other sources

$$
(n=2)
$$

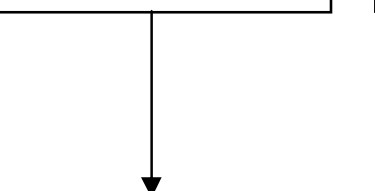

Articles after duplicate removed

$(n=53)$

Articles exclude by their title

$$
(n=29)
$$

Articles screened by abstract $(\mathrm{n}=24)$

Articles exclude by their abstract $(n=11)$

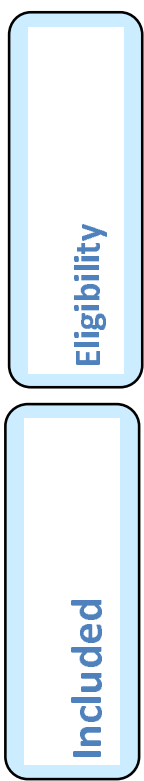

1 full-text articles excluded on the

Full-text articles assessed for eligibility

$$
(\mathrm{n}=13)
$$

$\longrightarrow \begin{array}{ll}1 & \begin{array}{l}\text { full-text articles } \\ \text { excluded on the } \\ \text { quality assessment }\end{array}\end{array}$

Figure 1. Flow chart diagram showing the selection of articles for systemic review and metaanalysis of poor glycemic control and associated factors among diabetic patients in Ethiopia 2019. 
medRxiv preprint doi: https://doi.org/10.1101/19004986; this version posted August 22, 2019. The copyright holder for this preprint (which was not certified by peer review) is the author/funder, who has granted medRxiv a license to display the preprint in perpetuity.

It is made available under a CC-BY-NC-ND 4.0 International license.

\section{Study characteristics}

In the meta-analysis total of 12 studies were included. Majority 5(41.67\%) of the study were from Amhara region of the country, three (25\%) from Oromia, two (16.67\%) from Tigray and two (16.67\%) from Addis Ababa the capital city of Ethiopia. All of the studies were cross sectional in study design and the largest sample size was in Addis Ababa which was 423 and the smallest sample size was in Amhara region (Table 1). 
Table 1: Distribution of selected studies for the systemic review and meta-analysis of poor glycemic control and associated factors among diabetic patients in Ethiopia, 2019

\begin{tabular}{|c|c|c|c|c|c|c|c|c|}
\hline S. № & $\begin{array}{l}\text { Author(publication } \\
\text { year) }\end{array}$ & Region & $\begin{array}{l}\text { Study } \\
\text { design }\end{array}$ & $\begin{array}{l}\text { Study } \\
\text { setting }\end{array}$ & $\begin{array}{l}\text { Sample } \\
\text { size }\end{array}$ & Resposerate $(\%)$ & $\begin{array}{l}\text { Blood } \\
\text { glucose } \\
\text { measured } \\
\text { by }\end{array}$ & $\begin{array}{l}\text { Poor } \\
\text { glycemic } \\
\text { control }(\%)\end{array}$ \\
\hline 1 & $\begin{array}{l}\text { Abebe, S. et al } \\
(2015)\end{array}$ & Amhara & $\begin{array}{l}\text { cross } \\
\text { sectional }\end{array}$ & hospital & 407 & 100 & $\mathrm{HbA1c}$ & 64.7 \\
\hline 2 & $\begin{array}{l}\text { Ayele, } \\
\text { \&Tegegn, } \\
\text { H.(2019) }\end{array}$ & Amhara & $\begin{array}{l}\text { cross } \\
\text { sectional }\end{array}$ & hospital & 278 & 98.9 & FBG & 57.1 \\
\hline 3 & $\begin{array}{l}\text { Cheneke, W. et. } \\
\text { Al (2016) }\end{array}$ & Oromia & $\begin{array}{l}\text { cross } \\
\text { sectional }\end{array}$ & hospital & 148 & 100 & HA1C & 59.5 \\
\hline 4 & $\begin{array}{l}\text { Demoz, G. et.al } \\
\text { (2019) }\end{array}$ & $\begin{array}{l}\text { Addis } \\
\text { ababa }\end{array}$ & $\begin{array}{l}\text { cross } \\
\text { sectional }\end{array}$ & hospital & 423 & 84.4 & FBG & 68.3 \\
\hline 5 & Fasil et al (2018) & Amhara & $\begin{array}{l}\text { cross } \\
\text { sectional }\end{array}$ & hospital & 367 & 100 & FBG & 60.5 \\
\hline 6 & $\begin{array}{l}\text { Fiseha, } \mathrm{T} \text { et.al } \\
(2018)\end{array}$ & Amhara & $\begin{array}{l}\text { cross } \\
\text { sectional }\end{array}$ & hopspital & 384 & 100 & FBG & 70.8 \\
\hline 7 & Fseha, B. (2017) & Tigray & $\begin{array}{l}\text { cross } \\
\text { sectional }\end{array}$ & hospital & 200 & 100 & FBG & 63.5 \\
\hline 8 & $\begin{array}{l}\text { Gebre-Yohannes, } \\
\text { A. \&Rahlenbeck, } \\
\text { S. I. (1997) }\end{array}$ & Amhara & $\begin{array}{l}\text { cross } \\
\text { sectional }\end{array}$ & hospital & 102 & 100 & HA1C & 77 \\
\hline 9 & $\begin{array}{ll}\text { Kassahun, } & \text { T. } \\
\text { et.al (2016) } & \end{array}$ & Oromia & $\begin{array}{l}\text { cross } \\
\text { sectional }\end{array}$ & hospital & 325 & 95 & FBG & 70.9 \\
\hline 10 & $\begin{array}{l}\text { Mideksa et.al } \\
(2018)\end{array}$ & Tigray & $\begin{array}{l}\text { comparative } \\
\text { cross } \\
\text { sectional }\end{array}$ & hospital & 336 & 100 & HA1C & 61.9 \\
\hline 11 & $\begin{array}{l}\text { Shimels, T. et.al } \\
(2018)\end{array}$ & $\begin{array}{l}\text { Addis } \\
\text { ababa }\end{array}$ & $\begin{array}{l}\text { cross } \\
\text { sectional }\end{array}$ & hospital & 414 & 87.2 & FBG & 60.3 \\
\hline 12 & $\begin{array}{ll}\text { Yigazu, } & \text { D. } \\
\text { \&Desse, } & \text { T. } \\
(2017) & \end{array}$ & Oromia & $\begin{array}{l}\text { cross } \\
\text { sectional }\end{array}$ & hospital & 74 & 100 & FBG & 59.2 \\
\hline
\end{tabular}


Table 2: Distribution of factors associated with poor glycemic control in the selected studies in Ethiopia, 2019

Number of Poor glycemic control

\begin{tabular}{|c|c|c|c|c|c|c|c|c|c|c|c|c|c|c|c|c|}
\hline \multirow{2}{*}{$\begin{array}{l}\text { S. } \\
\text { № }\end{array}$} & \multirow{2}{*}{$\begin{array}{l}\text { Author(publication } \\
\text { year) }\end{array}$} & \multicolumn{3}{|l|}{ age } & \multicolumn{2}{|l|}{ Sex } & \multicolumn{2}{|c|}{ Residence } & \multicolumn{2}{|c|}{ Income } & \multicolumn{2}{|c|}{ Occupation } & \multicolumn{2}{|c|}{ Educational status } & \multicolumn{2}{|c|}{ comorbidity } \\
\hline & & $\begin{array}{l}\text { Age } \\
>65\end{array}$ & $\begin{array}{l}\text { Age } \\
25-65\end{array}$ & $\begin{array}{l}\text { Age } \\
<25\end{array}$ & male & female & Urban & Rural & poor & rich & $\begin{array}{l}\text { empl } \\
\text { oyed }\end{array}$ & $\begin{array}{l}\text { unemp } \\
\text { loyed }\end{array}$ & $\begin{array}{l}\text { Formal } \\
\text { education }\end{array}$ & $\begin{array}{l}\text { No formal } \\
\text { education }\end{array}$ & Yes & no \\
\hline 1 & Abebe, S. et al (2015) & 32 & 195 & 25 & 125 & 128 & 215 & 38 & 167 & 52 & & & & & 98 & 155 \\
\hline \multirow[t]{2}{*}{2} & $\begin{array}{l}\text { Ayele, A. \&Tegegn, } \\
\text { H.(2019) }\end{array}$ & 24 & 133 & & 83 & 74 & 99 & 58 & 90 & 38 & & 33 & 47 & 100 & & \\
\hline & $\begin{array}{l}\text { Cheneke, W. et. Al } \\
(2016)\end{array}$ & & & & 50 & 38 & & & & & & & 57 & 31 & & \\
\hline 4 & $\begin{array}{l}\text { Demoz, G. et.al } \\
(2019)\end{array}$ & 96 & 148 & & 74 & 170 & 206 & 38 & & & 135 & 109 & 171 & 33 & 195 & 49 \\
\hline 5 & Fasil et al (2018) & 30 & 162 & 30 & 106 & 116 & 157 & 65 & & & 139 & 83 & 138 & 99 & & \\
\hline 6 & Fiseha, T et.al (2018) & & & & & & 181 & 91 & & & 145 & 126 & 150 & 121 & & \\
\hline 7 & Fseha, B. (2017) & 5 & 119 & 2 & 83 & 43 & 88 & 38 & 65 & 24 & & & 82 & 45 & 44 & 82 \\
\hline 8 & $\begin{array}{l}\text { Kassahun, T. et.al } \\
\text { (2016) }\end{array}$ & & & & & & & & & & 172 & 47 & 138 & 81 & & \\
\hline 9 & Mideksa et.al (2018) & 34 & 142 & 32 & & & 189 & 19 & 163 & 39 & & & & & & \\
\hline 10 & $\begin{array}{lll}\text { Shimels, } & \text { T. et.al } \\
(2018) & & \end{array}$ & 45 & 174 & & 119 & 100 & & & & & & & & & 118 & 101 \\
\hline 11 & $\begin{array}{l}\text { Yigazu, D. \&Desse, } \\
\text { T. (2017) }\end{array}$ & & & & 49 & 54 & & & & 52 & & & 51 & 50 & & \\
\hline
\end{tabular}


Table 3: Distribution of factors associated with poor glycemic control in the selected studies in Ethiopia, 2019

\begin{tabular}{|c|c|c|c|c|c|c|c|c|c|c|c|c|c|c|c|c|}
\hline \multirow{3}{*}{$\begin{array}{l}\text { S. } \\
\text { № }\end{array}$} & \multirow{3}{*}{ Author(publication year) } & \multicolumn{15}{|c|}{ Number of Poor glycemic control } \\
\hline & & \multicolumn{2}{|c|}{ Duration } & \multicolumn{2}{|c|}{$\begin{array}{l}\text { Dyslipide } \\
\text { mia }\end{array}$} & \multicolumn{2}{|c|}{$\begin{array}{l}\text { Medication } \\
\text { adherence }\end{array}$} & \multicolumn{3}{|c|}{ Drug taken } & \multicolumn{2}{|c|}{$\begin{array}{l}\text { physical } \\
\text { exercise }\end{array}$} & \multicolumn{2}{|c|}{$\begin{array}{l}\text { Diet } \\
\text { adherence }\end{array}$} & \multicolumn{2}{|c|}{$\begin{array}{l}\text { Body mass index } \\
\text { (BMI) }\end{array}$} \\
\hline & & $\begin{array}{l}\geq 10 \\
\text { year }\end{array}$ & $\begin{array}{l}<10 \\
\text { year }\end{array}$ & Yes & no & Yes & No & Insulin & oral & Both & Yes & No & Yes & No & Normal & $\begin{array}{l}\text { Over } \\
\text { Weight }\end{array}$ \\
\hline 1 & Abebe, S. et al (2015) & & 133 & 41 & 75 & 98 & 154 & 154 & 99 & & 174 & 75 & & & & \\
\hline 2 & $\begin{array}{l}\text { Ayele, A. \&Tegegn, } \\
\text { H.(2019) }\end{array}$ & 32 & 125 & & & & & & & & & & & & & \\
\hline 3 & Cheneke, W. et. Al (2016) & 14 & 74 & & & & & 46 & 39 & 3 & & & & & 48 & 24 \\
\hline 4 & Demoz, G. et.al (2019) & & & 199 & 45 & 65 & 102 & 36 & 13 & 71 & 163 & 81 & 62 & 192 & 15 & 229 \\
\hline 5 & Fasil et al (2018) & & 152 & 139 & 83 & & & 113 & 90 & 17 & & & & & 133 & 73 \\
\hline 6 & Fiseha, T et.al (2018) & 84 & 188 & & & & & 70 & 185 & 17 & & & & & & \\
\hline 7 & Fseha, B. (2017) & & 73 & & & 62 & 65 & & & & 45 & 82 & 38 & 89 & 101 & 17 \\
\hline 8 & Kassahun, T. et.al (2016) & & & & & 63 & 156 & 58 & 130 & 31 & & & & & & \\
\hline 9 & Mideksa et.al (2018) & & & 115 & 93 & & & 70 & 117 & 12 & & & & & & \\
\hline 10 & Shimels, T. et.al (2018) & 31 & 188 & & & 181 & 38 & 23 & 37 & 52 & 184 & 23 & 72 & 83 & & \\
\hline 11 & $\begin{array}{l}\text { Yigazu, D. \&Desse, T. } \\
\text { (2017) }\end{array}$ & 66 & 37 & & & & & & & & & & & & & \\
\hline
\end{tabular}




\section{Pooled prevalence of poor glycemic control among diabetic patients}

The pooled prevalence of poor glycemic control among diabetic patients in Ethiopia is $64.72 \%$ with 95\% confidence interval 63.16-66.28. Heterogeneity test was checked in this analysis and it was $\mathrm{I}^{2}=73.8 \%$ indicating of no heterogeneity. Egger's test was used to test for publication bias and $\mathrm{t}$-test $=-48, \mathrm{p}$-value $=0.638$, hence we declare that there were no publication bias in this analysis. Figure 2

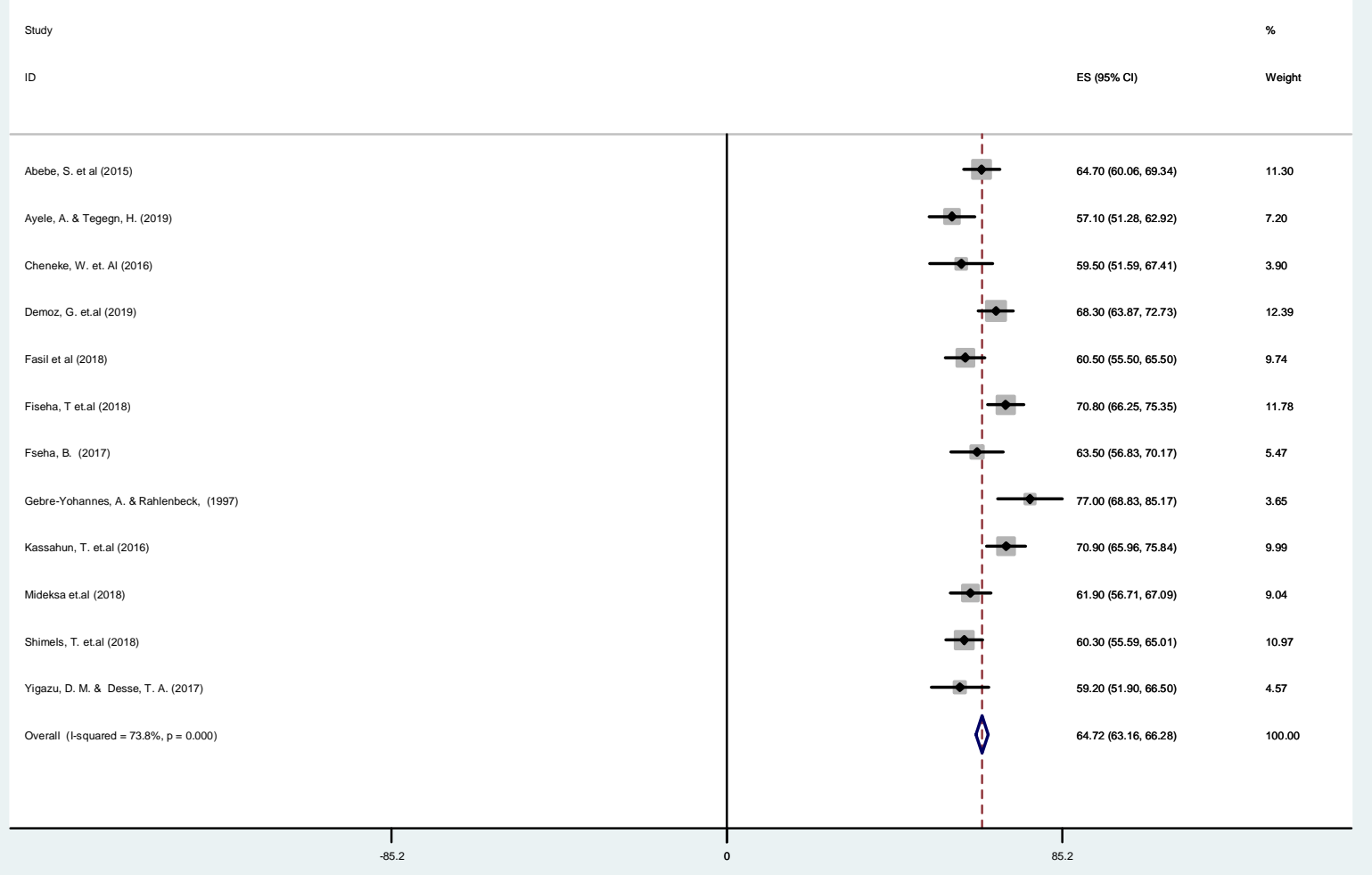

Figure 2: forest plot of the 12 studies assessed for the pooled prevalence of poor glycemic control among diabetic patients in Ethiopia, 2019. 


\section{Sensitivity test}

Sensitivity test has been conducted in the quantitative meta-analysis of poor glycemic control among diabetic patients in Ethiopia for the selected studies and all of the articles were with in the $95 \%$ confidence interval. Figure 3.

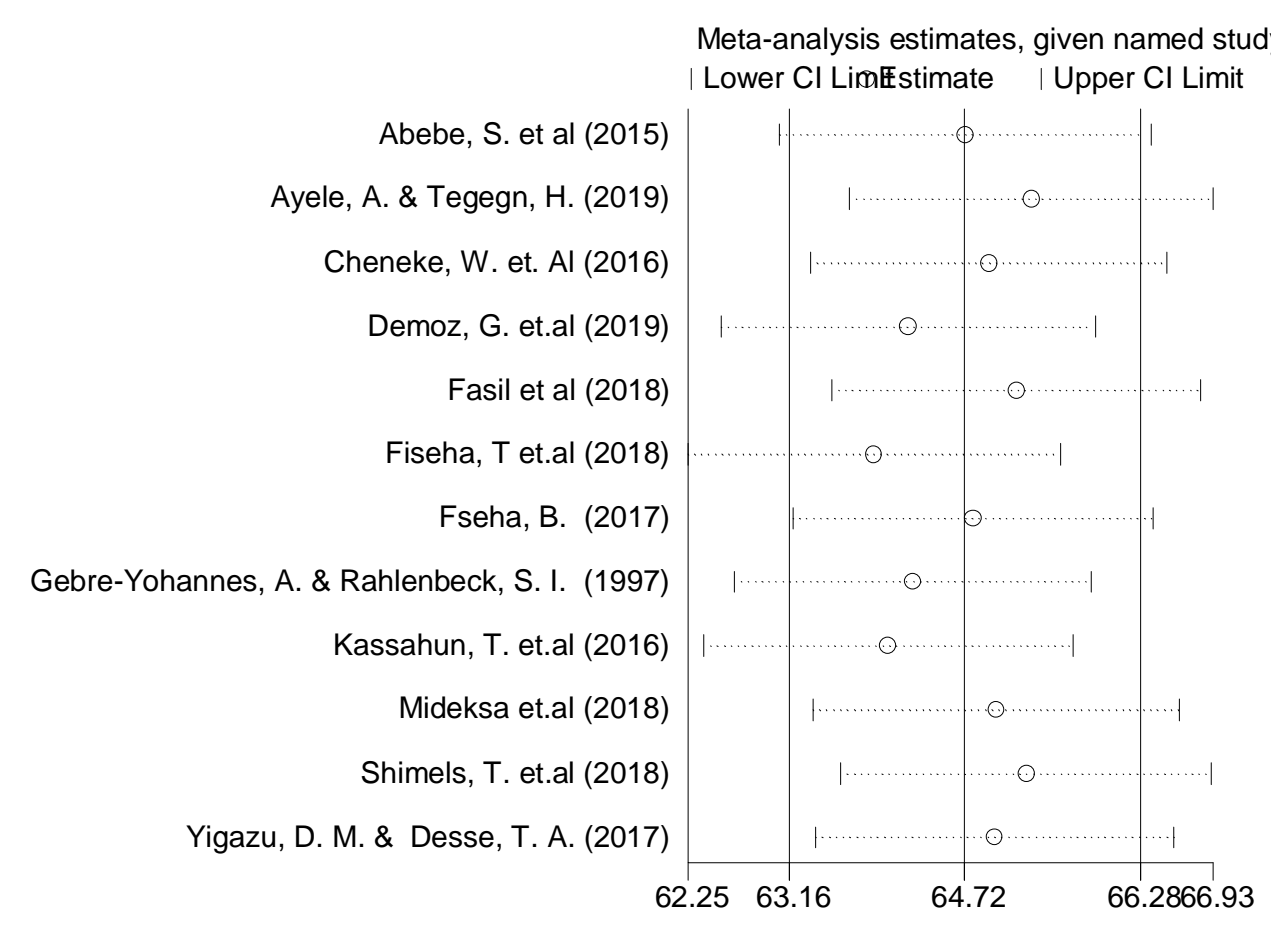

Figure 3: meta-analysis estimates of sensitivity test for the selected studies on poor glycemic control among diabetic patients in Ethiopia, 2019.

\section{Subgroup analysis of poor glycemic control by region of the country}

The sub group analysis of poor glycemic control among diabetic patients in different region of the country shows consistent and high prevalence of poor glycemic control ranging from $62.5 \%$ in Tigray region to $65.6 \%$ in Oromia region of the country. In Amhara region five studies have been included in the meta-analysis and the overall prevalence of poor glycemic control among diabetic patients was $65.18 \%$. (Figure 4 ). 


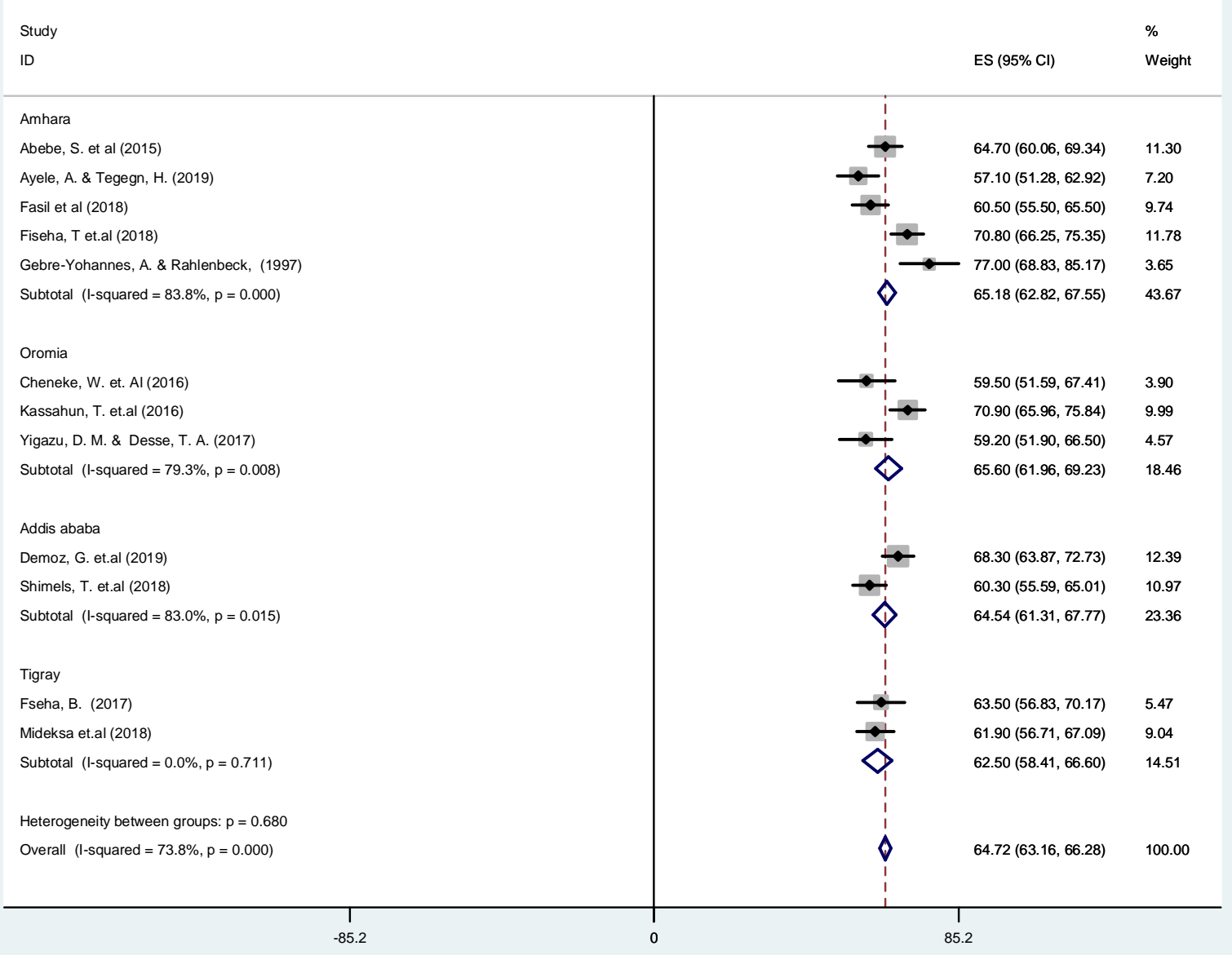

Figure 4: forest plot showing sub group anlysis byregion of the country of the poor glycemicin Ethiopia, 2019

\section{Subgroup analysis of poor glycemic control by method of measuring blood glucose level}

The subgroup analysis of poor glycemic control among diabetic patients by the fasting blood glucose (FBG) and by glycated hemoglobin (HbA1c) shows that there was no difference in the result of poor glycemic control. Eight studies has been included in quantitative meta analysis of the systemic review measured by fasting blood glucose and the overall poor glycemic control measured by FBG was $64.74 \%$. Studies measured the poor glycemic control in the review were four and the overall poor glycemic contral was $64.68 \%$. Figure 5 


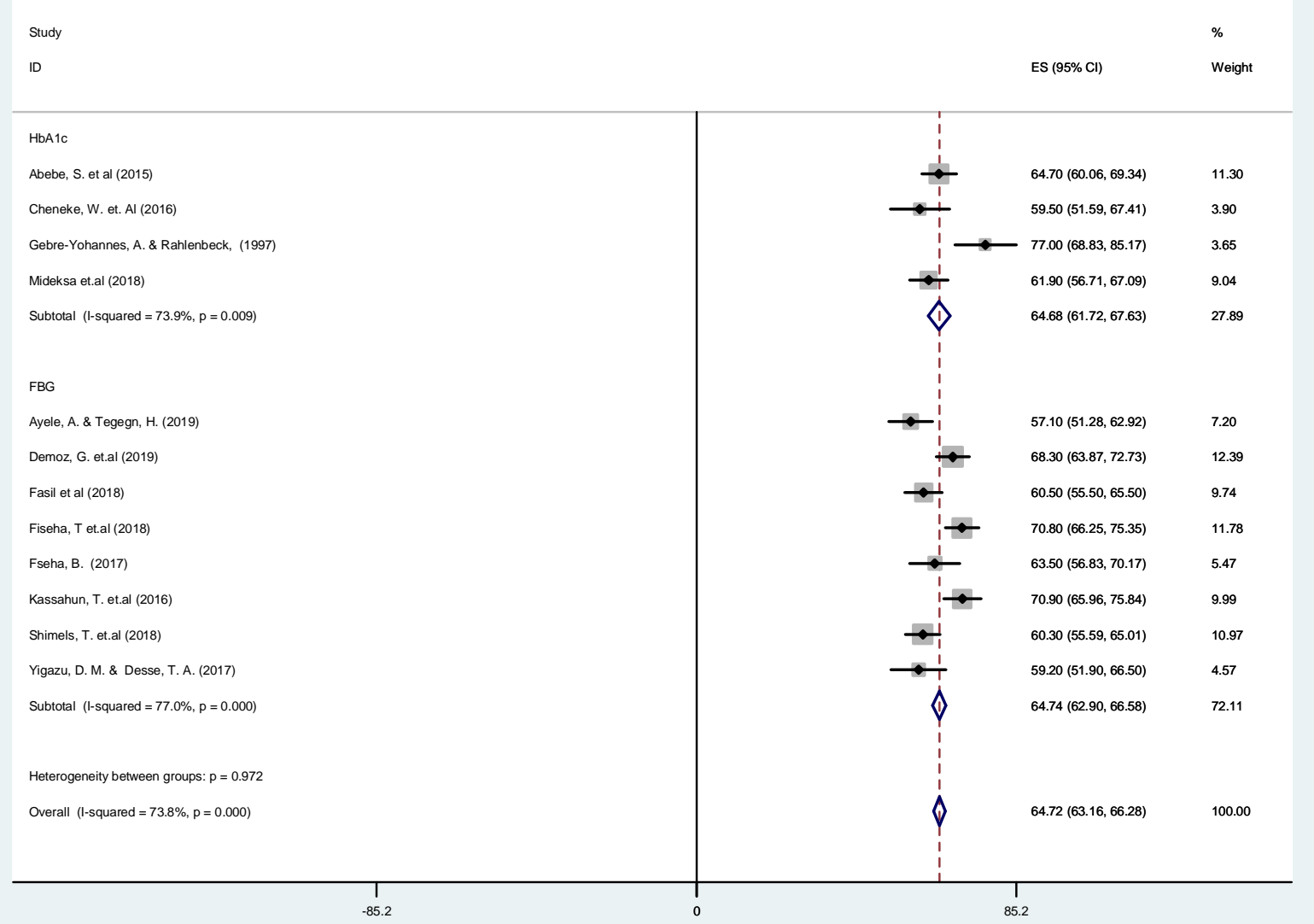

Figure 5: forest plot showing sub group anlysis by method of measuring blood glucose level of the poor glycemicin Ethiopia, 2019

\section{Factors associated with poor glycemic control among diabetic patients}

To identify factors that have significant association with poor glycemic control among diabetic patients we had conducted the quantitative meta-analysis of with random and fixed effect model based on the heterogeneity of the studies and random effect model is the more conservative method. There were a total of 14 factors investigated for poor glycemic control, among those only residence, dyslipidemia and diet adherence were significantly associated with poor glycemic control among diabetic patients in Ethiopia after conducting meta-analysis. 


\section{Residence}

In the quantitative meta-analysis total of seven studies have been including to identify residence (rural/urban) as a significant factor associated with poor glycemic control. Fixed effect model was used because there was no heterogeneity $\left(\mathrm{I}^{2}=0.0 \%, \mathrm{p}=0.43\right)$. Being rural residence was 1.74 times more likely to have poor glycemic control among diabetic patients as compared to urban residences. Figure 6

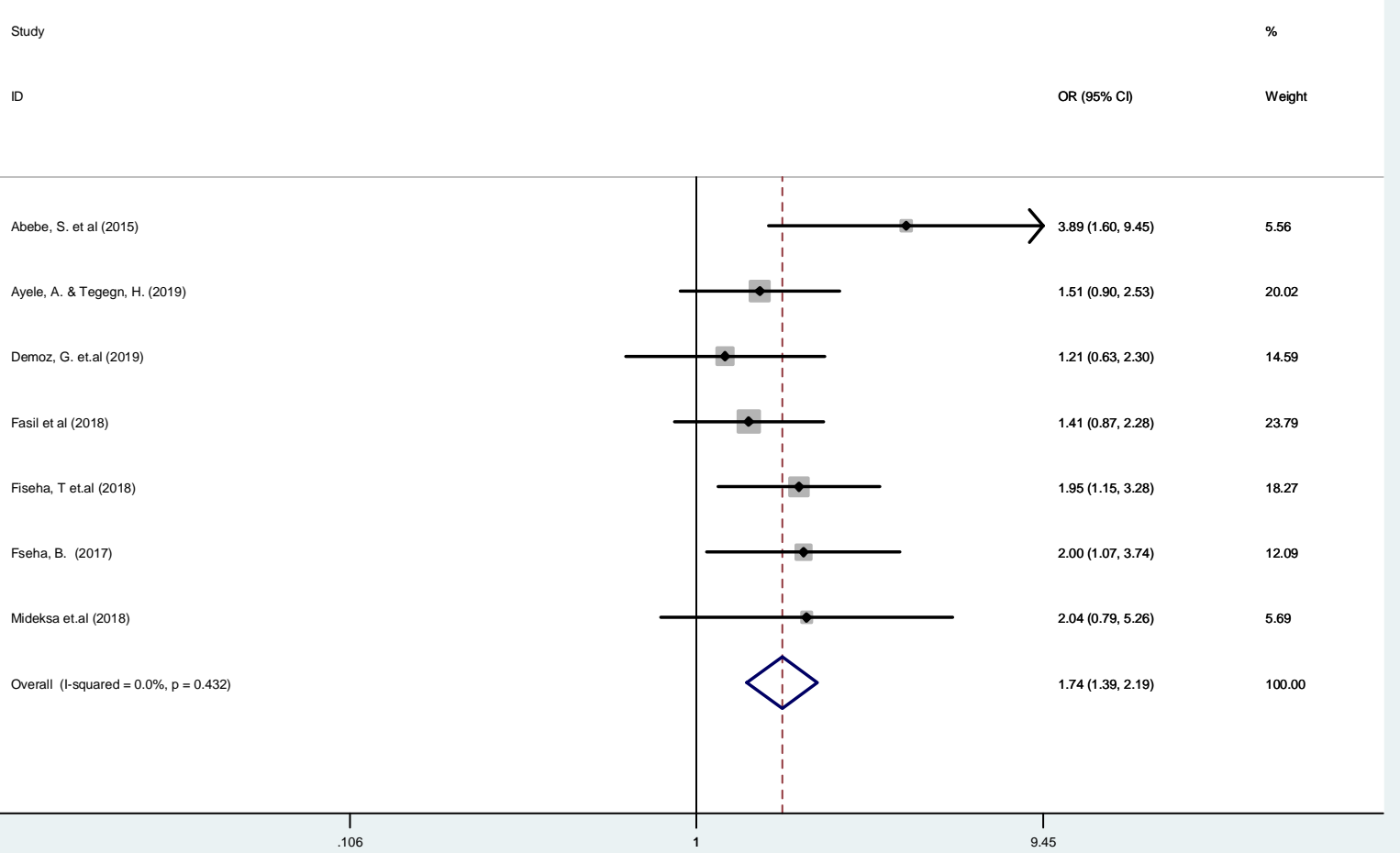

Figure 6: Forest plot showing the pooled significance of residence (rural/urban) with poor glycemic control among diabetic patients in Ethiopia, 2019.

\section{Dyslipidemia}

In the quantitative meta-analysis total of four studies have been including to identify dyslipidemia (normal lipid level/abnormal lipid level) as a significant factor associated with poor glycemic control. Random effect model was used because there was heterogeneity $\left(\mathrm{I}^{2}=84.3 \%\right.$, 
$\mathrm{p}=<0.001$ ). Being dyslipidemia was 4.69 times more likely to have poor glycemic control among diabetic patients as compared to patients that had normal level of blood lipids. Figure 7

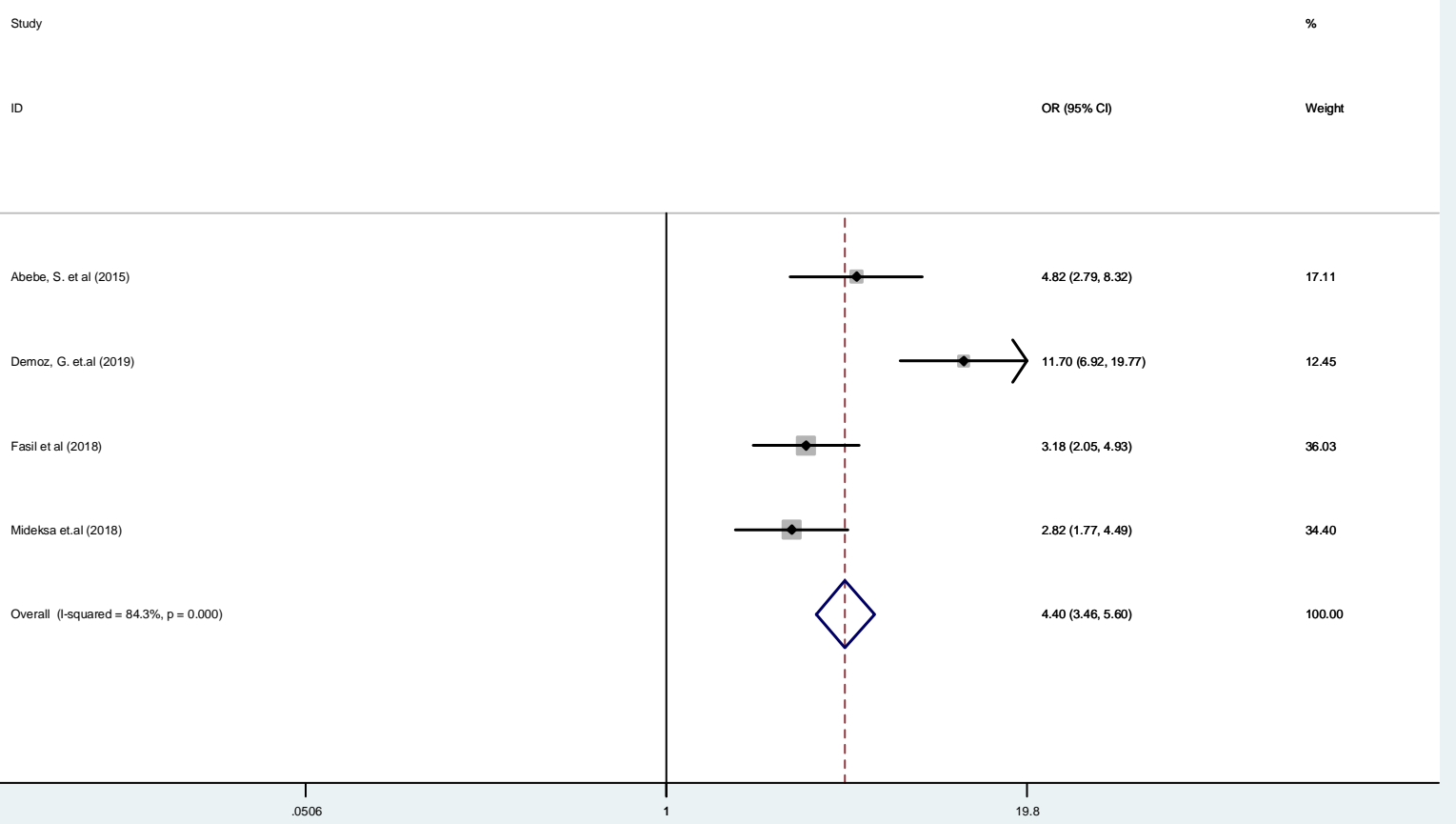

Figure 7: Forest plot showing the pooled significance of dyslipidemia (abnormal/normal) with poor glycemic control among diabetic patients in Ethiopia, 2019

\section{Diet adherence}

In the quantitative meta-analysis total of three studies have been including to identify dietary plan adherence as a significant factor associated with poor glycemic control. Random effect model was used because there was heterogeneity $\left(\mathrm{I}^{2}=90 \%, \mathrm{p}=<0.001\right)$. Being not adhered to the dietary plan was 5.45 times more likely to have poor glycemic control among diabetic patients as compared to patients that adhere to the dietary plan. Figure 8 


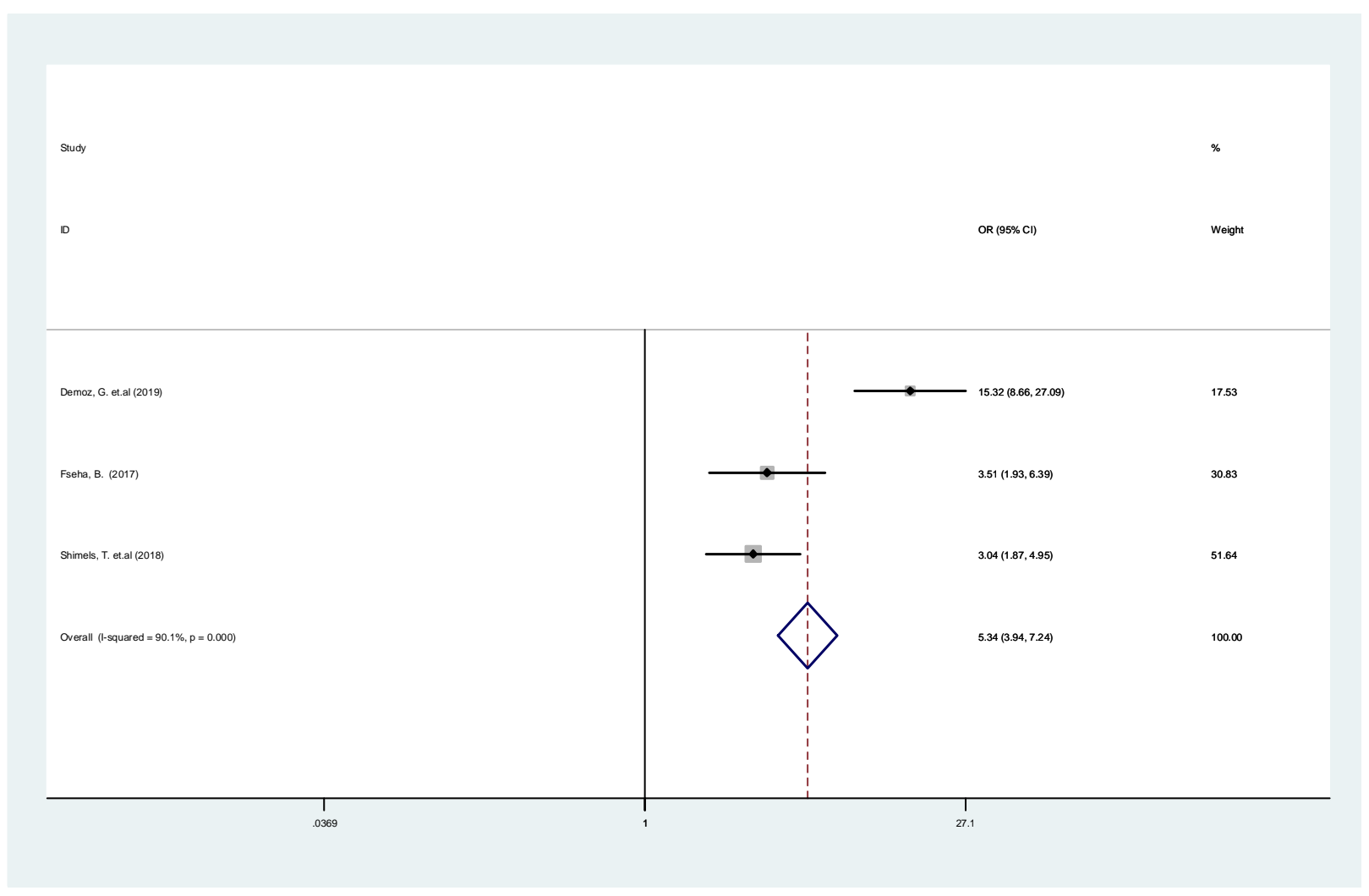

Figure 8: Forest plot showing the pooled significance of dietary plan adherence with poor glycemic control among diabetic patients in Ethiopia, 2019.

\section{Discussion}

Poor glycemic control among diabetic patients is the major cause of macro vascular and micro vascular complication and lead to hospital admissions.

In the current systemic review and meta-analysis a total of twelve studies have been used to summarize the pooled prevalence of poor glycemic control and their associated factors among diabetic patients in Ethiopia. The overall pooled prevalence of poor glycemic among diabetic patients was $64.72 \%$ and being rural residence, dyslipidemia, and not adhering to dietary plan were factors that had significant association with poor glycemic control.

The result of poor glycemic control in the current study $64.72 \%$ with $95 \% \mathrm{CI}(63.16-66.28)$ is consistent with study conducted in Jordan 65.1\%, (9), India 63\% (10),. However the current 
finding is higher than a study conducted in china 50.3\%(12), Zimbabwe 58.2\% (13), Israel 58.4\%(14). This discrepancy might be due to the study population characteristics, study design and the kind of medication they were given. Besides, the pooled prevalence of poor glycemic control among diabetic patients is lower than a study conducted in Bangladish 82\% (19), manipal/India 78.2\%(20), 78.6\% , Kenya 91.8\%(21), Saudi Arabia 74.9\%(22). This variation could be due to the measurement tool used for the outcome determination.

In the Meta analysis to identify significant factors associated with poor glycemic control among diabetic patient's twelve studies has been included. Being rural residence was 1.74 times more likely to have poor glycemic control as compared to urban residence( $\mathrm{OR}=1.72,95 \% \mathrm{CI}$ 1.39,2.19), this result is in line with a study conducted in Bangladesh(19),. This could be explained by peoples living in rural residence might have lower awareness, and also may not have sufficient access to health facility for professional support to maintain their glycemic control as compared to urban residences(25).

In addition being dyslipidemia was 4.69 times more likely to have poor glycemic control as compared to the patients having normal lipid level ( $\mathrm{OR}=4.69,95 \% \mathrm{CI} 2.51,8.71$ ) this result is in line with a study conducted by Kakade A. et al 2018 in Mumbai/India(21), systemic review by mohammad J. et al 2018 in Arabian gulf countries(26),. This could be due to the fact that continuous entry of fatty acids in to the $\beta$-cells of the pancreas creates $\beta$-cell lipotoxicity and this causes pancreases $\beta$-cell failure follow on poor glycemic control(27-29).

Similarly finding of this study revealed being no adherent to the dietary plan was 5.45 more likely to have poor glycemic control as compared to patients that adhere to their dietary paln ( $\mathrm{OR}=5.45,95 \% \mathrm{CI} 1.99,14.92$ ) this result is in line with a study conducted by Kakade A. et al 2018 in Mumbai/India(21), systemic review by Mohammad J. et al 2018 in Arabian gulf countries(26), and Khattab M. et al. 2010 in Jordan(9). This could be due to the fact that diet is the most important treatment that can modify may aspects of the body physiology including the pathophysiology of pancreas that secretes the hormone insulin(5). 
medRxiv preprint doi: https://doi.org/10.1101/19004986; this version posted August 22, 2019. The copyright holder for this preprint (which was not certified by peer review) is the author/funder, who has granted medRxiv a license to display the preprint in perpetuity.

It is made available under a CC-BY-NC-ND 4.0 International license .

\section{Conclusion}

The prevalence of poor glycemic control among diabetic patients was high in Ethiopia and consistent across different regions of the country. The most important factors associated with poor glycemic factor among diabetic patients were being rural residence, having dyslipidemia and not adhering to dietary plan.

\section{Abbreviations}

FBG: Fasting blood glucose, HbA1c: Glycated hemoglobin, BMI: Body Mass Index.

\section{Declarations}

\section{Ethics approval and consent to participate}

N/A

\section{Consent for publication}

\section{Not applicable}

\section{Availability of data and material}

The datasets used and/or analyzed during the current study are available from the corresponding author on reasonable request.

\section{Competing interests}

The authors declare) that they have no competing interests

\section{Funding}

There was no any fund for the current study

\section{Authors contributions}

BFT participated in the preparation of the design of the study, data analysis, write up and preparing daft of the manuscript and critically reviewing. Similarly AKB and GGW, participated in the design of the study, data analysis and presentation, reviewing of the manuscript. All authors read, accepted and approved the final manuscript

\section{Acknowledgement}


medRxiv preprint doi: https://doi.org/10.1101/19004986; this version posted August 22, 2019. The copyright holder for this preprint (which was not certified by peer review) is the author/funder, who has granted medRxiv a license to display the preprint in perpetuity. It is made available under a CC-BY-NC-ND 4.0 International license .

\section{References}

1. Aynalem SB, Zeleke AJ. Prevalence of Diabetes Mellitus and Its Risk Factors among Individuals Aged 15 Years and Above in Mizan-Aman Town, Southwest Ethiopia, 2016: A Cross Sectional Study. Int J Endocrinol. 2018;2018:9317987.

2. international diabetic federation. IDF Diabetes atlas. 2017;8th editio.

3. Lipsky BA, Apelqvist J, Bakker K, Netten JJ Van, Schaper NC. The challenge of diabetes in sub-Saharan Africa. 2015;8587(15):675-7.

4. Cheneke W, Suleman S, Yemane T, Abebe G. Assessment of glycemic control using glycated hemoglobin among diabetic patients in Jimma University specialized hospital, Ethiopia. BMC Res Notes. 2016 Feb;9:96.

5. Hospital S, Tigray N, Fseha B. Journal of Diabetes \& Metabolism Glycemic Control and it's Associated Factors in Type 2 Diabetic Patients. 2017;8(3).

6. Mideksa S, Ambachew S, Biadgo B, Baynes HW. Glycemic control and its associated factors among diabetes mellitus patients at Ayder comprehensive specialized hospital, Mekelle-Ethiopia. Adipocyte [Internet]. 2018 Jul 3;7(3):197-203. Available from: https://doi.org/10.1080/21623945.2018.1467716

7. Kassahun T, Eshetie T, Gesesew H. Factors associated with glycemic control among adult patients with type 2 diabetes mellitus: a cross-sectional survey in Ethiopia. BMC Res Notes. 2016 Feb;9:78.

8. Modesti PA. PA Modesti et al. Panethnic differences in blood pressure in europe: a systematic review and meta-analysis. S1 Text. :1-2.

9. Khattab M, Khader YS, Al-Khawaldeh A, Ajlouni K. Factors associated with poor glycemic control among patients with type 2 diabetes. J Diabetes Complications. 2010;24(2):84-9.

10. De P, Banu S, Muthukumar D. Predictors of poor glycemic control in type 2 diabetic patients in South Indian population. Int J Res Med Sci Vol 6, No 2 Febr 2018 [Internet]. 2018; Available from: https://www.msjonline.org/index.php/ijrms/article/view/4211/3681 
medRxiv preprint doi: https://doi.org/10.1101/19004986; this version posted August 22, 2019. The copyright holder for this preprint (which was not certified by peer review) is the author/funder, who has granted medRxiv a license to display the preprint in perpetuity. It is made available under a CC-BY-NC-ND 4.0 International license .

11. Abebe S, Berhane Y, Worku A, Alemu S, Gedlu N. Level of sustained Glycemic control and associated factors among patients with diabetes mellitus in Ethiopia: A hospital-based cross-sectional study. Diabetes, Metab Syndr Obes Targets Ther. 2015 Jan 25;8:65-71.

12. Li J, Chattopadhyay K, Xu M, Chen Y, Hu F, Chu J, et al. Glycaemic control in type 2 diabetes patients and its predictors: a retrospective database study at a tertiary care diabetes centre in Ningbo, China. BMJ Open [Internet]. 2018 Mar 1;8(3):e019697. Available from: http://bmjopen.bmj.com/content/8/3/e019697.abstract

13. Chirombe M, Ngara B, Chibvongodze R, Charuka V. Glucose Control in Diabetic Patients Attending Parirenyatwa Group of Hospitals in Zimbabwe. 2018;12-9.

14. Shani M, Taylor TR, Vinker S, Lustman A, Erez R, Elhayany A, et al. Characteristics of Diabetics with Poor Glycemic Control Who Achieve Good Control. J Am Board Fam Med [Internet]. 2008 Nov 1;21(6):490 LP-496. Available from: http://www.jabfm.org/content/21/6/490.abstract

15. Ayele AA, Tegegn HG, Ayele TA, Ayalew MB. Medication regimen complexity and its impact on medication adherence and glycemic control among patients with type 2 diabetes mellitus in an Ethiopian general hospital. BMJ open diabetes Res care. 2019;7(1):e000685.

16. Fasil A, Biadgo B, Abebe M. Glycemic control and diabetes complications among diabetes mellitus patients attending at University of Gondar Hospital, Northwest Ethiopia. Diabetes Metab Syndr Obes [Internet]. 2018 Dec 21;12:75-83. Available from: https://www.ncbi.nlm.nih.gov/pubmed/30613158

17. Yigazu DM, Desse TA. Glycemic control and associated factors among type 2 diabetic patients at Shanan Gibe Hospital, Southwest Ethiopia. BMC Res Notes. 2017 Nov;10(1):597.

18. Shimels T, Abebaw M, Bilal AI, Tesfaye T. Treatment Pattern and Factors Associated with Blood Pressure and Fasting Plasma Glucose Control among Patients with Type 2 Diabetes Mellitus in Police Referral Hospital in Ethiopia. Ethiop J Health Sci. 2018 $\mathrm{Jul} ; 28(4): 461-72$. 
medRxiv preprint doi: https://doi.org/10.1101/19004986; this version posted August 22, 2019. The copyright holder for this preprint (which was not certified by peer review) is the author/funder, who has granted medRxiv a license to display the preprint in perpetuity. It is made available under a CC-BY-NC-ND 4.0 International license .

19. Afroz A, Ali L, Karim MN, Alramadan MJ, Alam K, Magliano DJ, et al. Glycaemic Control for People with Type 2 Diabetes Mellitus in Bangladesh - An urgent need for optimization of management plan. Sci Rep [Internet]. 2019;9(1):10248. Available from: https://doi.org/10.1038/s41598-019-46766-9

20. Haghighatpanah M, Nejad ASM, Haghighatpanah M, Thunga G, Mallayasamy S. Factors that Correlate with Poor Glycemic Control in Type 2 Diabetes Mellitus Patients with Complications. Osong public Heal Res Perspect [Internet]. 2018 Aug;9(4):167-74. Available from: https://www.ncbi.nlm.nih.gov/pubmed/30159222

21. Kakade AA, Mohanty IR, Rai S. Assessment of factors associated with poor glycemic control among patients with Type II Diabetes mellitus. 2018;4(3):1-6.

22. Alzaheb RA, Altemani AH. The prevalence and determinants of poor glycemic control among adults with type 2 diabetes mellitus in Saudi Arabia. Diabetes Metab Syndr Obes [Internet]. 2018 Jan 31;11:15-21. Available from: https://www.ncbi.nlm.nih.gov/pubmed/29430192

23. Demoz GT, Gebremariam A, Yifter H, Alebachew M, Niriayo YL, Gebreslassie G, et al. Predictors of poor glycemic control among patients with type 2 diabetes on follow-up care at a tertiary healthcare setting in Ethiopia. BMC Res Notes. 2019 Apr;12(1):207.

24. Fiseha T, Alemayehu E, Kassahun W, Adamu A, Gebreweld A. Factors associated with glycemic control among diabetic adult out-patients in Northeast Ethiopia. BMC Res Notes. 2018 May;11(1):316.

25. Supiyev A, Kossumov A, Kassenova A, Nurgozhin T. Diabetes prevalence, awareness and treatment and their correlates in older persons in urban and rural population in the Astana region, Kazakhstan. Diabetes Res Clin Pract [Internet]. 2015;112:6-12. Available from: http://dx.doi.org/10.1016/j.diabres.2015.11.011

26. Alramadan MJ, Afroz A, Hussain SM, Batais MA, Almigbal TH, Al-humrani HA, et al. Review Article Patient-Related Determinants of Glycaemic Control in People with Type 2 Diabetes in the Gulf Cooperation Council Countries $\square$ : A Systematic Review. 2018;2018. 
medRxiv preprint doi: https://doi.org/10.1101/19004986; this version posted August 22, 2019. The copyright holder for this preprint (which was not certified by peer review) is the author/funder, who has granted medRxiv a license to display the preprint in perpetuity. It is made available under a CC-BY-NC-ND 4.0 International license.

27. Straub LG, Efthymiou V, Grandl G, Balaz M, Challa TD, Truscello L, et al. Antioxidants protect against diabetes by improving glucose homeostasis in mouse models of inducible insulin resistance and obesity. Diabetologia [Internet]. 2019; Available from: https://doi.org/10.1007/s00125-019-4937-7

28. Kitessa SM, Abeywardena MY. Lipid-Induced Insulin Resistance in Skeletal Muscle: The Chase for the Culprit Goes from Total Intramuscular Fat to Lipid Intermediates, and Finally to Species of Lipid Intermediates. Nutrients [Internet]. 2016 Jul 29;8(8):466. Available from: https://www.ncbi.nlm.nih.gov/pubmed/27483311

29. Acosta-Montaño P, García-González V. Effects of Dietary Fatty Acids in Pancreatic Beta Cell Metabolism, Implications in Homeostasis. Nutrients [Internet]. 2018 Mar

22;10(4):393. Available from: https://www.ncbi.nlm.nih.gov/pubmed/29565831 